Synthesis, characterization and biological activity of $\left(E_{1}, E_{2}\right) N^{1}, N^{2}-$ bis[1-(3,4dihydroxyphenyl)ethylidene]oxalohydrazide complexes: New method for $\mathrm{ZrO}^{2+}$ separation Ahmed A. El-Asmy*, Ola A. Al-Gammal, Heba A. Radwan and Shaban E. Ghazy Chemistry Department, Faculty of Science, Mansoura University, Mansoura, Egypt. aelasmy@yahoo.com

Abstract: The bond length, bond angle, HOMO, LUMO, dipole moment and charges on the atoms have been calculated to confirm the geometry of $\left(E_{1}, E_{2}\right) N^{1}, N^{2}-$ bis[1-(3,4-dihydroxyphenyl)ethylidene]oxalohydrazide, $\mathrm{H}_{6} \mathrm{DPOH}$. The metal complexes of $\mathrm{Cr}^{3+}, \mathrm{VO}^{2+}, \mathrm{ZrO}^{2+}$, $\mathrm{HfO}^{2+}, \mathrm{UO}_{2}{ }^{2+}$ and $\mathrm{MoO}_{2}{ }^{2+}$ with $\mathrm{H}_{6} \mathrm{DPOH}$ have been prepared and characterized by partial elemental analysis, spectral studies (electronic; IR), thermal analysis and magnetic measurements. The data suggest the formation of $\left[\mathrm{Cr}\left(\mathrm{H}_{4} \mathrm{DPOH}\right)\left(\mathrm{H}_{2} \mathrm{O}\right)_{3} \mathrm{Cl}\right] \mathrm{H}_{2} \mathrm{O}, \quad\left[\mathrm{VO}\left(\mathrm{H}_{4} \mathrm{DPOH}\right)\left(\mathrm{H}_{2} \mathrm{O}\right)_{2}\right]$, $\left[\mathrm{Hf}\left(\mathrm{H}_{4} \mathrm{DPOH}\right)\left(\mathrm{H}_{2} \mathrm{O}\right)\right] \mathrm{H}_{2} \mathrm{O} \quad\left[\mathrm{UO}_{2}\left(\mathrm{H}_{4} \mathrm{DPOH}\right)\left(\mathrm{H}_{2} \mathrm{O}\right)_{2}\right] 2 \mathrm{H}_{2} \mathrm{O}$ $\left[\mathrm{MoO}_{2}\left(\mathrm{H}_{4} \mathrm{DPOH}\right)\right]$ and $\left[(\mathrm{ZrO})_{2}\left(\mathrm{H}_{2} \mathrm{DPOH}\right)\left(\mathrm{C}_{2} \mathrm{H}_{5} \mathrm{OH}\right)_{2}\right]$. $\mathrm{H}_{6} \mathrm{DPOH}$ behaves as a dibasic bidentate in all complexes except $\mathrm{ZrO}^{2+}$ which acts as a tetrabasic tetradentate for the two $\mathrm{ZrO}^{2+}$ ions. An octahedral geometry was proposed for the $\mathrm{Cr}^{3+}, \mathrm{HfO}^{2+}, \mathrm{MoO}_{2}{ }^{2+}$ and $\mathrm{UO}_{2}{ }^{2+}$ complexes and square pyramid for $\mathrm{VO}^{2+}$. The $\mathrm{Cr}(\mathrm{III})$ or $\mathrm{VO}^{2+}$ complexes are necessary to degrade the DNA of Eukaryotic subject completely; the other complexes have little effect. $\mathrm{H}_{6}$ DPOH was found applicable as a new reagent for the separation and preconcentration of $\mathrm{ZrO}^{2+}$ ions from different water samples using flotation technique with satisfactory results.

Keywords: $\left(\mathrm{E}_{1}, \mathrm{E}_{2}\right) \mathrm{N}^{1}, \mathrm{~N}^{2}$ - bis[1-(3,4-dihydroxyphenyl) ethylidene]oxalohydrazide.

Introduction

Great interest has been focused on the synthesis and structural characterization of metal complexes of hydrazones in order to compare their coordinative behavior with their antimicrobial activities. Certain hydrazones and their $\mathrm{Cu}(\mathrm{II})$ complexes have antitumor activity (Ranford et al., 1998). Diacetylmonoxime thiosemicarbazone is effective against vaccinia infections in mice by chelating some essential metal ions from the virus (Periin, 1976). Oximinohydrazones have antiparasitic, fungicidal and bactericidal properties (ElAsmy et al., 2001). Compounds containing oxime and amino groups are used as analytical reagents for the microdetermination of some transition metal ions and as ion exchange resins (El-Asmy et al., 1998). Previous papers (Mostafa et al., 1983; Shallaby et al., 1984; Huo et al., 2004; El-Asmy et al., 2000; Saracoglu et al., 2004; Latha et al., 2004; El-Asmy et al., 2000) were reported on the synthesis and characterization of some oxime hydrazone complexes.

Up to date, no work was done on complexes containing $\mathrm{Cr}^{3+}, \mathrm{VO}^{2+}, \mathrm{ZrO}^{2+}, \mathrm{HfO}^{2+}, \mathrm{UO}_{2}{ }^{2+}$ and $\mathrm{MoO}_{2}{ }^{2+}$ ions with the investigated ligand, $\mathrm{H}_{6} \mathrm{DPOH}$.

Experimental

VOSO $\mathrm{S}_{4} .2 \mathrm{H}_{2} \mathrm{O}, \mathrm{CrCl}_{3} .3 \mathrm{H}_{2} \mathrm{O}, \mathrm{ZrCl}_{4}, \mathrm{HfCl}_{4}, \mathrm{UO}_{2}(\mathrm{OAc})_{2}$ and $\left(\mathrm{NH}_{4}\right)_{2} \mathrm{MoO}_{4}$, diethyl oxalate, hydrazine hydrate, 3,4- dihydroxybenzaldehyde, ethanol, diethyl ether, DMF and DMSO were obtained from the BDH chemicals.

Synthesis of $\mathrm{H}_{6} \mathrm{DPOH}$

$\left(E_{1}, E_{2}\right) N^{1}, N^{2}$ bis(1-(3,4-dihydroxyphenyl)ethylidene) oxalohydrazide, Fig. 1, was prepared by heating a suspension $(6 \mathrm{~g}, 0.05 \mathrm{~mol})$ of oxalic acid dihydrazide $\left(\mathrm{NH}_{2} \mathrm{NHCOCONHNH}_{2}\right)$ in $20 \mathrm{~mL}$ EtOH with $13.8 \mathrm{~g}(0.1$ mol) of 3,4-dihydroxybenzaldehyde in $10 \mathrm{~mL} E t O H$ on a water bath for one day. Complete reaction is tested by TLC in petroleum ether-ethyl acetate (1:2) as eluent. It gives one spot with "Rf" $=0.34$. The precipitate was filtered off, recrystallized from ethanol and dried; the yield is $79 \%$. The ligand was characterized by spectral studies and elemental analysis. The ${ }^{1} \mathrm{H}$ NMR spectrum of the ligand gives different signals at $\delta=12.05,9.48,7.41-6.85$ and $2.32 \mathrm{ppm}$, corresponding to the protons of $\mathrm{OH}, \mathrm{NH}$, aromatic $\mathrm{CH}$ and aliphatic $\mathrm{CH}$, respectively.

\section{Preparation of complexes}

The solid complexes were prepared by reacting the calculated amounts for $2: 1$ ratio [M:L] of metal salt and ligand in $\mathrm{H}_{2} \mathrm{O}-\mathrm{EtOH}(\mathrm{v} / \mathrm{v})$ solution and the mixture was heated under reflux on a water bath for 6-8 h. In the preparation of $\mathrm{VO}^{2+}$ complex, $0.1 \mathrm{~g}$ of sodium acetate was added. The precipitate thus formed was filtered off, washed with hot water, hot ethanol and diethyl ether and finally dried in a vacuum desiccator over anhydrous $\mathrm{CaCl}_{2}$.

\section{Flotation method}

A $3 \mathrm{ml}$ aliquot containing $0.5 \times 10^{-5} \mathrm{~mol} \mathrm{I}^{-1} \mathrm{ZrO}^{2+}$ was mixed with $\mathrm{H}_{6} \mathrm{DPOH}\left(1 \times 10^{-4} \mathrm{~mol} \mathrm{I}^{-1}\right)$ and $3 \mathrm{ml}$ bidistilled water. The $\mathrm{pH}$ was adjusted at $\sim 3$. The solution was then transferred quantitatively to the flotation cell and completed to $10 \mathrm{ml}$ with double distilled water. The cell was shaken well for few seconds to ensure complete complexation. To this solution, $3 \mathrm{ml}$ of $1 \times 10^{-5} \mathrm{~mol} \mathrm{l}^{-1}$ oleic acid $(\mathrm{HOL})$ were added and the cell was then inverted upside down many times by hand. After complete separation, the scum containing $\mathrm{ZrO}^{2+}-\mathrm{H}_{6} \mathrm{DPOH}$ complex was separated, eluted with $4 \mathrm{ml}$ of $4 \mathrm{~mol} \mathrm{I}^{-1} \mathrm{HCl}$, diluted to $10 \mathrm{ml}$ in a volumetric flask and subjected to spectral determination.

\section{Antibacterial and genotoxicity studies}

The organic ligand and its metal complexes were screened for their antimicrobial activity using grampositive (BT) and gram-negative bacteria $(E$. coll). The media prepared for bacteria were as reported earlier (AlGammal \& El-Asmy, 2008). For a genotoxicity study, a solution of $2 \mathrm{mg}$ of Calf thymus DNA was dissolved in 1 $\mathrm{ml}$ of sterile distilled water where the investigated ligand and its complexes were prepared by dissolving $2 \mathrm{mg} / \mathrm{ml}$ DMSO. An equal volume of each compound and DNA were mixed thoroughly and kept at room temperature for
Research article

CIndian Society for Education and Environment (iSee)
"New method of $\mathrm{ZrO}^{2+}$ separation"

http://www.indjst.org
El-Asmy et al. Indian J.Sci.Technol. 
2-3 h. The effect of the compounds on the DNA was analyzed by agarose gel electrophoresis. A $2 \mu$ of loading dye was added to $15 \mu \mathrm{l}$ of the DNA mixture before being loaded into the well of an agarose gel. The loaded mixtures were fractionated by electrophoresis, visualized by UV and photographed.

\section{Equipment and analysis}

Carbon, hydrogen and nitrogen contents of the ligand and its complexes were determined at the Microanalytical Unit of Cairo University, Egypt. The metal content was determined by gravimetric or complexometric methods (Vogel, 1994). The IR spectra were recorded as $\mathrm{KBr}$ disc on a Mattson 5000 FTIR Spectrophotometer. The UV-Vis. spectra of the complexes were recorded on $\mathrm{UV}_{2}$ Unicam Spectrophotometer. The ${ }^{1} \mathrm{H}-\mathrm{NMR}$ spectrum of the ligand was recorded in deuterated DMSO (DMSOd6), on a Bruker WP 200 SY spectrometer at room temperature using TMS as an external standard. The magnetic measurements were carried out on a JohnsonMatthey magnetic balance, UK. Thermogravimetry was measured $\left(20-800{ }^{\circ} \mathrm{C}\right)$ on a Shimadzu TGA-50; the nitrogen flow and heating rate were $20 \mathrm{ml} \mathrm{min}^{-1}$ and $10{ }^{\circ} \mathrm{C}$ $\mathrm{min}^{-1}$, respectively. ESR spectra were obtained on a Bruker EMX spectrometer working in the X-band (9.78 $\mathrm{GHz}$ ) with $100 \mathrm{KHz}$ modulation frequency. The microwave power was set at 0.004 . A powder spectrum was obtained in a $2 \mathrm{~mm}$ quartz capillary at room temperature.

All molecular calculations were carried out by HyperChem 7.51 software package. The molecular geometry of the ligand and its $\mathrm{ZrO}^{2+}$ complex is first optimized at molecular mechanics $(\mathrm{MM}+)$ level. Semi empirical method PM3 is then used for optimizing the full geometry of the system using Polak-Ribiere (conjugate gradient) algorithm and Unrestricted Hartee-Fock (UHF) is employed keeping RMS gradient of $0.01 \mathrm{kcal} / \AA ̊ \mathrm{~mol}$.

Results and discussion

The data of elemental analysis together with some physical properties of the complexes are summarized in Table 1. The results confirm the formulae $\left[\mathrm{Cr}\left(\mathrm{H}_{4} \mathrm{DPOH}\right)\left(\mathrm{H}_{2} \mathrm{O}\right)_{3} \mathrm{Cl}\right] \mathrm{H}_{2} \mathrm{O},\left[\mathrm{M}\left(\mathrm{H}_{4} \mathrm{DPOH}\right)\left(\mathrm{H}_{2} \mathrm{O}\right)_{n}\right] \mathrm{mH}_{2} \mathrm{O}(\mathrm{M}$ $=\mathrm{VO}$, $\mathrm{HfO}, \mathrm{MoO}_{2}$ or $\mathrm{UO}_{2}$ ) and $\left[(\mathrm{ZrO})_{2}\left(\mathrm{H}_{2} \mathrm{DPOH}\right)\left(\mathrm{C}_{2} \mathrm{H}_{5} \mathrm{OH}\right)_{2}\right]$. The complexes are insoluble in most common organic solvents and partially soluble in DMF and DMSO. The partial solubility of the complexes in DMSO and /or DMF prevents the growing of crystals for X-ray crystallography and the measurement of their molar conductances and ${ }^{1} H$ NMR spectra. The intense color may be due to a charge transfer or a defect of crystal during the preparation. $\mathrm{HfO}^{2+}$ complex has a more intense color than $\mathrm{ZrO}^{2+}$ complex which may be due to high polarizability; this observation is supported by the appearance of a band at $14680 \mathrm{~cm}^{-1}$ in its electronic spectrum due to LMCT. The thermal analyses confirm a high stability for some complexes. This behavior may indicate a polymeric nature for these complexes.

Research article

CIndian Society for Education and Environment (iSee)

\section{Molecular modeling of the ligand}

The molecular numbering of the ligand is shown in Fig. 1. Analysis of the data in Tables $1 S$ and $2 S$ calculated for both length and angle for each bond in the ligand molecule, one can conclude the following remarks: 1-All bond lengths of the $\mathrm{O}-\mathrm{H}$ bonds are nearly similar.

2-All bond lengths of the $\mathrm{C}-\mathrm{O}$ bonds are nearly similar, except $\mathrm{C}(16)-\mathrm{O}(17)$ and $\mathrm{C}(13)-\mathrm{O}(15)$ which are smaller than the rest due to the double bond character.

3-The two N-N bond lengths are typical due to the similarity of moieties on the two sides.

4-All bond angles predict $\mathrm{sp}^{3}$ and $\mathrm{sp}^{2}$ hybridization.

5 -The bond angles of $\mathrm{C}(21)-\mathrm{N}(20)-\mathrm{N}(18), \mathrm{O}(17)-\mathrm{C}(16)-$ $\mathrm{C}(13)$ and $\mathrm{C}(16) \mathrm{C}(13)-\mathrm{O}(15)$ are $123.39,123.35$ and 124.87 while $\mathrm{C}(23)-\mathrm{C}(21)-\mathrm{N}(20)$ is $127.39^{\circ}$. The larger the substitutent moiety on $\mathrm{N}(20)$ the high stretching and the more bond angle.

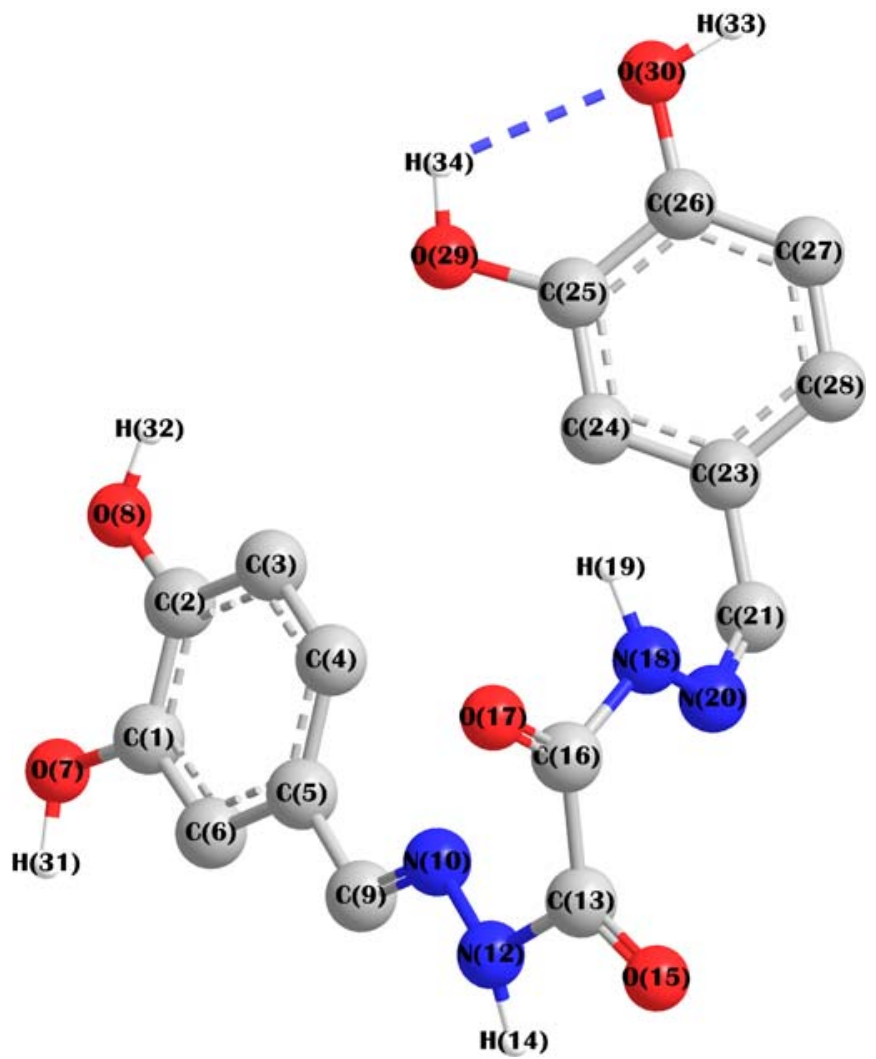

Fig. 1. Molecular modeling of $\mathrm{H}_{6} \mathrm{DPOH}$ (vide cover page -colour)

The molecular parameters calculated by hyperchem program are found as: total energy $=-1041311 \mathrm{kcal} / \mathrm{mol}$; binding energy = $-4295 \mathrm{kcal} / \mathrm{mol}$; electronic energy= $-740887 \mathrm{kcal} / \mathrm{mol}$; heat of formation $=-22 \mathrm{kcal} / \mathrm{mol}$; dipole moment $=3.144$ (Debyes); $\mathrm{HOMO}=-8.773392 \mathrm{eV}$ and LUMO $=-0.3302211 \mathrm{eV}$ are calculated. Tables $1 \mathrm{~S}$ and $2 \mathrm{~S}$ gathered the values calculated for the bond lengths and bond angles.

IR Spectra

The IR spectrum of the ligand showed bands at 3486 , 2363(w), 2338(w), 3374(w), 1653(vs), 1612(s), 1517(w) and $1366(\mathrm{~s})$ due to the $v(\mathrm{OH})_{\text {free }}, v(\mathrm{OH})_{\text {bonded }}, v(\mathrm{NH})$, 
Table 1. Color, melting points and partial elemental analyses of $H_{6} D P O H$ and its complexes

\begin{tabular}{|c|c|c|c|c|c|c|}
\hline Compound & Color & M.P, ${ }^{\circ} \mathrm{C}$ & C & $\%$ Found & Calcd.) & \\
\hline & & & & $\mathrm{H}$ & $\mathrm{N}$ & $\mathrm{M}$ \\
\hline $\begin{array}{l}\mathrm{H}_{6} \mathrm{DPOH} \\
\mathrm{C}_{16} \mathrm{H}_{14} \mathrm{~N}_{4} \mathrm{O}_{6}, 358.32\end{array}$ & $\begin{array}{l}\text { Pale } \\
\text { yellow }\end{array}$ & $295-96$ & $53.2(53.6)$ & $5.5(5.9)$ & $\begin{array}{l}14.9 \\
(15.6)\end{array}$ & - \\
\hline $\begin{array}{l}{\left[\mathrm{VO}\left(\mathrm{H}_{4} \mathrm{DPOH}\right)\left(\mathrm{H}_{2} \mathrm{O}\right)_{2}\right]} \\
\mathrm{C}_{16} \mathrm{H}_{16} \mathrm{~N}_{4} \mathrm{O}_{7} \mathrm{~V}, 459.27\end{array}$ & $\begin{array}{l}\text { Brownish } \\
\text { green }\end{array}$ & $>300$ & $\begin{array}{c}42.2 \\
(41.8)\end{array}$ & $\begin{array}{l}3.7 \\
(3.5)\end{array}$ & $\begin{array}{l}13.0 \\
(12.2) \\
\end{array}$ & $\begin{array}{l}11.4 \\
(11.1)\end{array}$ \\
\hline $\begin{array}{l}{\left[\mathrm{Cr}\left(\mathrm{H}_{4} \mathrm{DPOH}\right)\left(\mathrm{H}_{2} \mathrm{O}\right)_{3} \mathrm{Cl}\right] \mathrm{H}_{2} \mathrm{O}} \\
\mathrm{C}_{16} \mathrm{H}_{20} \mathrm{~N}_{4} \mathrm{O}_{10} \mathrm{CrCl}, 516.73\end{array}$ & Brown & $>300$ & $36.8(37.2)$ & $3.7(3.9)$ & $\begin{array}{l}10.4 \\
(10.8)\end{array}$ & $\begin{array}{l}10.5 \\
(10.1)\end{array}$ \\
\hline $\begin{array}{l}{\left[(\mathrm{ZrO})_{2}\left(\mathrm{H}_{2} \mathrm{DPOH}\right)\left(\mathrm{C}_{2} \mathrm{H}_{5} \mathrm{OH}\right)_{2}\right]} \\
\mathrm{C}_{20} \mathrm{H}_{22} \mathrm{~N}_{4} \mathrm{O}_{10} \mathrm{Zr}_{2}, 660.83\end{array}$ & $\begin{array}{l}\text { Yellowish } \\
\text { orange }\end{array}$ & $>300$ & $37.0(36.4)$ & $4.0(3.6)$ & $\begin{array}{l}8.1 \\
(8.5) \\
\end{array}$ & $\begin{array}{l}31.9 \\
(32.4 \\
\end{array}$ \\
\hline $\begin{array}{l}{\left[\mathrm{HfO}\left(\mathrm{H}_{4} \mathrm{DPOH}\right)\left(\mathrm{H}_{2} \mathrm{O}\right)\right] \mathrm{H}_{2} \mathrm{O}} \\
\mathrm{C}_{16} \mathrm{H}_{14} \mathrm{~N}_{4} \mathrm{O}_{8} \mathrm{Hf}, 586.84\end{array}$ & $\begin{array}{l}\text { Brownish } \\
\text { orange }\end{array}$ & $>300$ & $33.2(32.7)$ & $3.3(2.7)$ & $\begin{array}{l}8.9 \\
(9.5)\end{array}$ & - \\
\hline $\begin{array}{l}{\left[\mathrm{UO}_{2}\left(\mathrm{H}_{4} \mathrm{DPOH}\right)\left(\mathrm{H}_{2} \mathrm{O}\right)_{2}\right] 2 \mathrm{H}_{2} \mathrm{O}} \\
\mathrm{C}_{16} \mathrm{H}_{20} \mathrm{~N}_{4} \mathrm{O}_{12} \mathrm{U}, 698.45\end{array}$ & Brown & $>300$ & $26.9(27.5)$ & $3.3(2.9)$ & - & $\begin{array}{l}34.5 \\
(34.1)\end{array}$ \\
\hline $\begin{array}{l}{\left[\mathrm{MoO}_{2}\left(\mathrm{H}_{4} \mathrm{DPOH}\right)\right]} \\
\mathrm{C}_{16} \mathrm{H}_{12} \mathrm{~N}_{4} \mathrm{O}_{8}, 483.91\end{array}$ & $\begin{array}{l}\text { Brownish } \\
\text { green }\end{array}$ & $>300$ & $39.3(38.8)$ & $3.8(4.2)$ & $\begin{array}{l}11.8 \\
(11.6)\end{array}$ & - \\
\hline
\end{tabular}

Table 2. Assignments of the IR spectral bands of $\mathrm{H}_{6} \mathrm{DPOH}$ and its complexes

\begin{tabular}{|l|l|l|l|l|l|l|l|}
\hline Compound & $v(\mathrm{OH})$ & $v(\mathrm{NH})$ & $\mathrm{v}(\mathrm{C}=\mathrm{O})$ & $\mathrm{v}(\mathrm{C}=\mathrm{N})$ & $\begin{array}{l}{[\delta(\mathrm{N}-\mathrm{H})+} \\
\mathrm{v}(\mathrm{C}-\mathrm{N})]\end{array}$ & $\delta(\mathrm{OH})$ & $\mathrm{v}(\mathrm{M}-\mathrm{O})$ \\
\hline $\mathrm{H}_{6} \mathrm{DPOH}$ & $\begin{array}{l}3486, \\
2363,2338\end{array}$ & 3374 & 1653 & 1612 & 1517 & 1367 & - \\
\hline$\left[\mathrm{VO}\left(\mathrm{H}_{4} \mathrm{DPOH}\right)\left(\mathrm{H}_{2} \mathrm{O}\right)_{2}\right]$ & $\begin{array}{l}3396, \\
--\end{array}$ & 3242 & 1644 & 1593 & 1517 & 1366, & 468 \\
\hline$\left[\mathrm{Cr}\left(\mathrm{H}_{4} \mathrm{DPOH}\right)\left(\mathrm{H}_{2} \mathrm{O}\right)_{3} \mathrm{Cl}\right] \mathrm{H}_{2} \mathrm{O}$ & $\begin{array}{l}3343, \\
--\end{array}$ & 3247 & 1653 & 1611 & 1517 & $\begin{array}{l}1337^{*} \\
1366\end{array}$ & 470 \\
\hline$\left[(\mathrm{ZrO})_{2}\left(\mathrm{H}_{2} \mathrm{DPOH}\right)\left(\mathrm{C}_{2} \mathrm{H}_{5} \mathrm{OH}\right)_{2}\right]$ & -- & 3247 & 1656 & 1614 & 1515 & $1365^{*}$ & 466 \\
\hline$\left[\mathrm{HfO}\left(\mathrm{H}_{4} \mathrm{DPOH}\right)\left(\mathrm{H}_{2} \mathrm{O}\right) \mathrm{H}_{2} \mathrm{O}\right.$ & $\begin{array}{l}3442, \\
--\end{array}$ & 3247 & 1656 & 1614 & 1515 & $\begin{array}{l}1338^{*} \\
1359\end{array}$ & 464 \\
\hline$\left[\mathrm{UO}_{2}\left(\mathrm{H}_{4} \mathrm{DPOH}\right)\left(\mathrm{H}_{2} \mathrm{O}\right)_{2}\right] 2 \mathrm{H}_{2} \mathrm{O}$ & $\begin{array}{l}3344, \\
---\end{array}$ & 3247 & 1653 & 1607 & 1516 & 1369 & 467 \\
\hline$\left[\mathrm{MoO}_{2}\left(\mathrm{H}_{4} \mathrm{DPOH}\right)\right]$ & $\begin{array}{l}3419, \\
--\end{array}$ & 3180 & 1679 & 1589 & 1530 & 1372 & 521 \\
\hline
\end{tabular}

$v(\mathrm{C}=\mathrm{O}), v(\mathrm{C}=\mathrm{N})$, amide II $[\delta(\mathrm{N}-\mathrm{H})+v(\mathrm{C}=\mathrm{N})]$ and $\delta(\mathrm{OH})$ vibrations, respectively. The bands at 2363 and $2338 \mathrm{~cm}^{-1}$ are due to the O-H...O hydrogen bonding (El-Metwally et al., 2006).

The absence of the bands due to the free and bonded $\mathrm{OH}$ groups (Table 2) in the spectra of all complexes indicates the destruction of the hydrogen bond during complexation. Another band appears at 3396-3442 $\mathrm{cm}^{-1}$ in the spectra of all complexes, except for the $\mathrm{ZrO}^{2+}$ complex, indicating the involvement of only two OH's in chelation; the other two are still protonated with weak hydrogen bond. In $\mathrm{ZrO}^{2+}$ complex, no band in this region confirming the involvement of the four $\mathrm{OH}^{\prime}$ 's in coordination. Another support for the $\mathrm{OH}$ coordination is the appearance of $\delta(\mathrm{OH})$ band at $1366 \mathrm{~cm}^{-1}$ with low intensity as well as another one at $1338 \mathrm{~cm}^{-1}$. The new band may be due to $\delta(\mathrm{OH})$ of the coordinated water. Ethanol bonding in zirconyl complex is supported by the appearance of $\delta(\mathrm{OH})$ strong. The $v(\mathrm{NH}), v(\mathrm{C}=\mathrm{O})$ and $v(\mathrm{C}=\mathrm{N})$ bands appeared more or less at the same position as in the spectrum of $\mathrm{H}_{6} \mathrm{DPOH}$ indicating no chelation through these groups; these groups exist opposite to
1961) by: $\left(v_{3}\right)^{2}=(1307)^{2}\left(F_{U-0}\right) / 14.103$

each other (from molecular calculation). Also, the IR spectra of the metal chelates showed new band at $464-521 \mathrm{~cm}^{-1}$ due to $v(\mathrm{M}-\mathrm{O})$ (El-Asmy et al., 2008). In addition, the vanadyl complex showed a broad band at $970 \mathrm{~cm}^{-1}$ attributed to $v(\mathrm{~V}=\mathrm{O})$ which is a former evidence for the square-pyramidal configuration of the $\mathrm{VO}^{2+}$ complex (ElMetwally \& ElAsmy, 2006]. The

IR spectrum of $\left[\mathrm{UO}_{2}\left(\mathrm{H}_{4} \mathrm{DPOH}\right)\left(\mathrm{H}_{2}\right.\right.$ O) $\left.{ }_{2}\right] 2 \mathrm{H}_{2} \mathrm{O}$ displayed bands at 929 and 873 assigned to $v_{3}$ and $v_{1}$ of the dioxouranium ion (El-Sonbati et al., 1998). The $v_{3}$ value is used to calculate the force constant (F) of the $\mathrm{U}=\mathrm{O}$ bond (McGlynn \& Smith,

The force constant was then substituted into the Jones relation (Jones, 1958): $R_{\mathrm{U}-\mathrm{O}}=1.08\left(\mathrm{~F}_{\mathrm{U}-\mathrm{O}}\right)^{-1 / 3}+1.17$

The calculated $F_{U-o}$ and $R_{U-O}$ were 7.125 mdynes $\AA^{-1}$ and $1.73 \AA$, respectively, falling within the usual range for the uranyl complexes (El-Sonbati et al., 1998).

Analogous to the $\mathrm{UO}_{2}$ complex, the spectrum of $\mathrm{MoO}_{2}{ }^{2+}$ complex showed bands at 904 and $850 \mathrm{~cm}^{-1}$. Using the same equations, $\mathrm{F}_{\mathrm{Mo}-\mathrm{O}}$ and $\mathrm{R}_{\mathrm{Mo}-\mathrm{O}}$ are calculated to be 6.75 mdynes $\AA^{-1}$ and $1.74 \AA$, respectively. The radius of Mo-O is approximately similar to $\mathrm{U}-\mathrm{O}$.

The broad bands at 3361,890 and $540 \mathrm{~cm}^{-1}$ in the spectra of $\left[\mathrm{VO}\left(\mathrm{H}_{4} \mathrm{DPOH}\right)\left(\mathrm{H}_{2} \mathrm{O}\right)_{2}\right], \quad\left[\mathrm{Cr}\left(\mathrm{H}_{4} \mathrm{DPOH}\right)\right.$ $\left.\left(\mathrm{H}_{2} \mathrm{O}\right)_{3} \mathrm{Cl}\right] \mathrm{H}_{2} \mathrm{O}$ and $\left[\mathrm{UO}_{2}\left(\mathrm{H}_{4} \mathrm{DPOH}\right)\left(\mathrm{H}_{2} \mathrm{O}\right)_{2}\right]-2 \mathrm{H}_{2} \mathrm{O}$ are attributed to $\mathrm{U}(\mathrm{OH}), \rho_{\mathrm{r}}\left(\mathrm{H}_{2} \mathrm{O}\right)$ and $\rho_{\mathrm{w}}\left(\mathrm{H}_{2} \mathrm{O}\right)$, respectively, confirming water coordination (El-Asmy et al., 1994); these bands were absent in the other complexes.

Electronic and magnetic studies

The magnetic moment values measured for $\mathrm{VO}^{2+}$ and $\mathrm{Cr}^{3+}$ complexes are 1.74 and $3.57 \mathrm{BM}$, respectively, consistent with the presence of one and three unpaired
Research article

Clndian Society for Education and Environment (iSee)
"New method of $\mathrm{ZrO}^{2+}$ separation" http://www.indjst.org
El-Asmy et al. Indian J.Sci.Technol. 
Table 3. Magnetic moments and electronic spectral bands of the compounds

\begin{tabular}{|l|l|l|l|l|}
\hline Compound & $\begin{array}{l}\mu_{\text {eff }} \\
(B M)\end{array}$ & State & $\begin{array}{l}\text { Intraligand and charge } \\
\text { transfer }\left(\mathrm{cm}^{-1}\right)\end{array}$ & $\begin{array}{l}\text { d-d transition } \\
\left(\mathrm{cm}^{-1}\right)\end{array}$ \\
\hline $\mathrm{H}_{6} \mathrm{DPOH}$ & -- & DMF & $\begin{array}{l}35740 ; 33000 ; \\
32050 ; 27900 ; 26455\end{array}$ & -- \\
\hline$\left[(\mathrm{ZrO})_{2}\left(\mathrm{H}_{2} \mathrm{DPOH}\right)\left(\mathrm{C}_{2} \mathrm{H}_{5} \mathrm{OH}\right)_{2}\right]$ & 0.00 & DMF & $\begin{array}{l}36765 ; 32680 ; \\
27470\end{array}$ & - \\
\hline$\left[\mathrm{Cr}\left(\mathrm{H}_{4} \mathrm{DPOH}\right)\left(\mathrm{H}_{2} \mathrm{O}\right)_{3} \mathrm{Cl}_{2} \mathrm{H}_{2} \mathrm{O}\right.$ & 3.69 & DMF & $35970 ; 32895$ & $\begin{array}{l}22830 ; 21830 ; \\
18050 ; 16450\end{array}$ \\
\hline$\left[\mathrm{UO}_{2}\left(\mathrm{H}_{4} \mathrm{DPOH}\right)\left(\mathrm{H}_{2} \mathrm{O}\right)_{2}\right] 2 \mathrm{H}_{2} \mathrm{O}$ & 0.00 & DMSO & $\begin{array}{l}35710 ; 33110 ; 27860 ; \\
24340\end{array}$ & -- \\
\hline$\left[\mathrm{MoO}_{2}\left(\mathrm{H}_{4} \mathrm{DPOH}\right)\right]$ & 0.00 & $\begin{array}{l}\text { Nujol } \\
\text { DMF }\end{array}$ & $\begin{array}{l}34720 ; 31650 ; 27625 ; 26040 \mathrm{x} \\
33110 ; 28250 ; 24040 ; 19840\end{array}$ & -- \\
\hline$\left[\mathrm{VO}\left(\mathrm{H}_{4} \mathrm{DPOH}\right)\left(\mathrm{H}_{2} \mathrm{O}\right)_{2}\right]$ & 1.74 & Nujol & $33110 ; 28250 ; 23920$ & 19840 \\
\hline$\left[\mathrm{HfO}\left(\mathrm{H}_{4} \mathrm{DPOH}\right)\left(\mathrm{H}_{2} \mathrm{O}\right)\right] \mathrm{H}_{2} \mathrm{O}$ & 0.00 & Nujol & $\begin{array}{l}24330 ; 22330 ; \\
14640\end{array}$ & - \\
\hline
\end{tabular}

The electronic spectrum of $\left[\mathrm{MoO}_{2}\left(\mathrm{H}_{4} \mathrm{DPOH}\right]\right.$ in Nujol (DMF) shows bands at 34720 (33110), $31650, \quad 27625$ (28250) and $26040(24040) \mathrm{cm}^{-}$ due to intraligand transitions similar to those in the ligand spectrum. The band at 24040 $\mathrm{cm}^{-1}$ is similar to that in the $\mathrm{UO}_{2}$ spectrum indicating $\mathrm{O}=\mathrm{Mo}=\mathrm{O}$ moiety. The shoulder at 19840 $\mathrm{cm}^{-1}$ in DMF spectrum arose from $O$ pseudo-sigma combinations to the singly occupied Mo 4d orbital in the xy

Table 4. Effect of some foreign ions on the flotation of $5 \times 10^{5}$ $\mathrm{mol} \mathrm{L}^{-1} \mathrm{ZrO}^{2+}$ using $1 \times 10^{4} \mathrm{~mol}^{-1} \mathrm{H}_{6} \mathrm{DPOH}$ and $1 \times 10^{3} \mathrm{~mol} \mathrm{~L}^{-1}$ $\mathrm{HOL}$ at $p \mathrm{H}^{-3}$

\begin{tabular}{|c|c|c|c|c|c|}
\hline Cation & $\begin{array}{c}\text { Foreign/ } \\
\mathrm{ZrO}^{2+}\end{array}$ & $\mathrm{F}(\%)$ & Anion & $\begin{array}{c}\text { Foreign/ } \\
\mathrm{ZrO}^{2+}\end{array}$ & $\mathrm{F}(\%)$ \\
\hline $\mathrm{Na}^{+}$ & 200 & 99.2 & $\mathrm{Cl}^{-}$ & 200 & 99.4 \\
\hline $\mathrm{K}^{+}$ & 200 & 98.4 & $\mathrm{SO}_{4}{ }^{2-}$ & 20 & 92.2 \\
\hline $\mathrm{Ca}^{2+}$ & 200 & 98.5 & Citrate & 20 & 80.0 \\
\hline $\mathrm{Co}^{2+}$ & 20 & 99.5 & $\mathrm{HPO}_{4}{ }^{--}$ & 20 & 86.7 \\
\hline $\mathrm{Ni}^{2+}$ & 20 & 98.5 & $\mathrm{CH}_{3} \mathrm{COO}^{-}$ & 20 & 99.2 \\
\hline $\mathrm{Cu}^{2+}$ & 20 & 8.5 & & & \\
\hline $\mathrm{Zn}^{2+}$ & 20 & 75.8 & & & \\
\hline $\mathrm{Cd}^{2+}$ & 20 & 99.5 & & & \\
\hline $\mathrm{NH}_{4}{ }^{+}$ & 100 & 98.4 & & & \\
\hline $\mathrm{Al}^{3+}$ & 20 & 74.2 & & & \\
\hline
\end{tabular}

electrons. The other complexes have a diamagnetic nature in accordance with the $\mathrm{d}^{0}$ or $\mathrm{d}^{10}$ configuration.

The electronic spectrum of the ligand showed $\pi \rightarrow \pi^{*}$ and $n \rightarrow \Pi^{*}$ bands in the region $35740-26455 \mathrm{~cm}^{-1}$. Changes are observed on the spectra of its complexes (Table 3). The band at $24340 \mathrm{~cm}^{-1}$ in the spectrum of the $\mathrm{UO}_{2}{ }^{2+}$ complex may be due to LMCT.

The electronic spectrum of $\left[\mathrm{Cr}\left(\mathrm{H}_{4} \mathrm{DPOT}\right)\left(\mathrm{H}_{2} \mathrm{O}\right)_{3} \mathrm{Cl}\right] \mathrm{H}_{2} \mathrm{O}$ showed two strong absorption bands at 18050 and 22831 $\mathrm{cm}^{-1}$ attributed to the ${ }^{4} \mathrm{~A}_{2 \mathrm{~g}}(\mathrm{~F}) \rightarrow{ }^{4} \mathrm{~T}_{2 \mathrm{~g}}(\mathrm{P})\left(\mathrm{v}_{1}\right)$ and ${ }^{4} \mathrm{~A}_{2 \mathrm{~g}}(\mathrm{~F}) \rightarrow$ ${ }^{4} T_{1 g}(F)\left(V_{2}\right)$ transitions, in an octahedral geometry. An additional broad band centered at $24210 \mathrm{~cm}^{-1}$ is due to a charge transfer. The ligand field parameters $\left(D q=1805 \mathrm{~cm}^{-}\right.$ ${ }^{1}, \mathrm{~B}=429.8 \mathrm{~cm}^{-1}$ and $\beta=0.46$ ) are further support for the proposed geometry. The lower value of $\beta$ is indication of more covalency.

The presence of two bands at 23920 and $19840 \mathrm{~cm}^{-1}$ in $\left[\mathrm{VO}\left(\mathrm{H}_{4} \mathrm{DPOH}\right)\left(\mathrm{H}_{2} \mathrm{O}\right)_{2}\right]$ is assigned to the $d_{x z} \rightarrow d_{x y}$ transition (El-Metwally et al., 2005), in a squarepyramidal geometry. The color and IR band support the proposed structure.

The u.v. spectrum of $\left[\mathrm{UO}_{2}\left(\mathrm{H}_{4} \mathrm{DPOH}\left(\mathrm{H}_{2} \mathrm{O}\right)_{2}\right)\right] 2 \mathrm{H}_{2} \mathrm{O}$ showed a band at $24340 \mathrm{~cm}^{-1}$ assigned to $\sum_{\mathrm{g}} \rightarrow^{3} \pi_{4}$ similar to the $\mathrm{O}=\mathrm{U}=\mathrm{O}$ symmetric stretching frequency for the first excited state (McGlynn et al., 1961). plane suggesting a considerable covalency in the groundstate electronic structure of $\left[\mathrm{MoO}_{2}\left(\mathrm{H}_{4} \mathrm{DPOH}\right]_{\mathrm{n}}\right.$ (Fig. 2). There is no evidence of any $\mathrm{d}-\mathrm{d}$ transition and the data supported the six coordination of the complex (Syamal et al., 1986; McMaster et al., 2001).

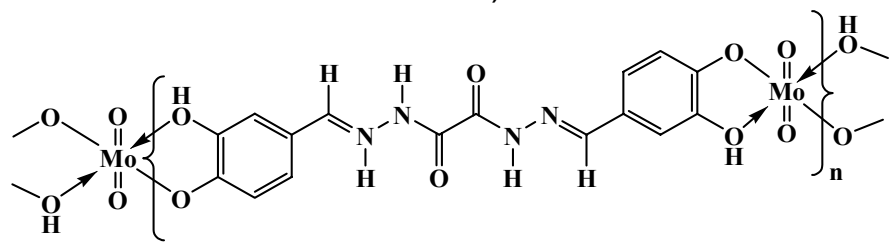

\section{Thermal analysis}

Fig. 2. Formulae of $\left[\mathrm{MoO}_{2}\left(\mathrm{H}_{4} \mathrm{DPOH}\right]_{n}\right.$

The thermogravimetric curves $\left(25-800^{\circ} \mathrm{C}\right)$ of some complexes were recorded to give an insight into the thermal stability of the complexes studied. In $\mathrm{Cr}^{3+}$ and $\mathrm{HfO}^{2+}$, the first decomposition step is due to loss of water of crystallization in the temperature range $40-150^{\circ} \mathrm{C}$. In the other complexes, the first decomposition step begins at 205,207 and $268^{\circ} \mathrm{C}$.

The TG curve of $\left[\mathrm{VO}\left(\mathrm{H}_{4} \mathrm{DPOH}\right)\left(\mathrm{H}_{2} \mathrm{O}\right)_{2}\right.$ ] displayed a thermal stability till $205{ }^{\circ} \mathrm{C}$, after which five degradation steps were observed at $205-285,286-353,355-434$, $435-515$ and $516-730^{\circ} \mathrm{C}$. The first decomposition step is due to the removal of the two coordinated water molecules with 8.0 (Calcd. 7.8\%) weight losses. $\mathrm{C}_{7} \mathrm{H}_{4} \mathrm{NO}_{2} \mathrm{VO}$ still exists in the last step by 40.7 (Calcd. $40.9 \%$ ) revealing a high stability of the final species at the final decomposition temperature $\left(730^{\circ} \mathrm{C}\right)$.

In $\left[(\mathrm{ZrO})_{2}\left(\mathrm{H}_{2} \mathrm{DPOH}\right)\left(\mathrm{C}_{2} \mathrm{H}_{5} \mathrm{OH}\right)_{2}\right]$, the decomposition begins at $268{ }^{\circ} \mathrm{C}$ indicating a high stability of the complex. The first step at $269-362{ }^{\circ} \mathrm{C}$ is due to the removal of $2 \mathrm{C}_{2} \mathrm{H}_{5} \mathrm{OH}+\mathrm{C}_{4} \mathrm{H}_{2} \mathrm{O}_{2}$. The final step ending at $800{ }^{\circ} \mathrm{C}$ corresponds to $\mathrm{Zr}_{2} \mathrm{O}_{3}$ as a residual part.

\section{ESR spectral studies}

The ESR spectrum of the vanadyl complex (Fig. 3) provides information about hyperfine and superhyperfine structures which are important in studying the metal ion in the complexes. Generally, the mononuclear $\mathrm{VO}^{2+}$ ion $(\mathrm{S}=$ $1 / 2, \quad I=7 / 2$ ) has a characteristic octet ESR spectrum showing the hyperfine coupling to the ${ }^{51} \mathrm{~V}$ nuclear magnetic moment. Upon the existence of two vanadyl 
ions, the two electron spins may combine to a non-magnetic spin singlet $(S=0)$ or a paramagnetic spin triplet state $(S=1)$; only the latter is ESR detectable. The superexchange interaction between the two vanadium ions lead to a configuration in which the two electron spins have an antiferromagnetic character, i.e. the singlet state is energetically favored (Thaker et al., 1994). Therefore, the ESR spectrum of strongly coupled pairs has the form of a single broad line with inhomogeneous broadening.

Vanadium(IV) complexes generally have g-values less than the g-value " $g_{\mathrm{e}}$ " of the free electron 2.0023 (admixture of empty MO's).

The room temperature $(300 \mathrm{~K})$ ESR spectrum of $\left[\mathrm{VO}\left(\mathrm{H}_{4} \mathrm{DPOH}\right)\left(\mathrm{H}_{2} \mathrm{O}\right)_{2}\right]$ gave a typical eightline pattern (Fig. 3) similar to those reported for mononuclear vanadium molecule (Khasaa et al., 2003). In the powdered mono vanadium complexes, the spectra showed the parallel and the perpendicular features which indicate axially symmetric anisotropy with well resolved sixteenlines hyperfine splitting characteristic for the interaction between the electron and the vanadium nuclear spin $(I=$ 7/2) (Raman et al., 2003). The spin Hamiltonian parameters are calculated to be $g_{/ /}(1.93), g_{\perp}$ (1.97), $A_{/ /}$ $\left(190 \times 10^{-4} \mathrm{~cm}^{-1}\right)$ and $A_{\perp}(60)$. The calculated ESR parameters indicate that the unpaired electron $\left(d^{1}\right)$ is present in the $d_{x y}$-orbital with square-pyramidal or octahedral geometry. The values obtained agree well with the g-tensor parameters reported for square pyramidal geometry (Kiverlson \& Lee, 1964).

The molecular orbital coefficients $\alpha^{2}$ and $\beta^{2}$ for $\left[\mathrm{VO}\left(\mathrm{H}_{4} \mathrm{DPOH}\right)\left(\mathrm{H}_{2} \mathrm{O}\right)_{2}\right]$ were calculated by the well-known equations and found to be 0.93 and 0.77 , respectively. The lower value of $\beta^{2}$ compared to $\alpha^{2}$ indicates that the inplane $\sigma$-bonding is less covalent and are well consistent with other reported data (Warad et al., 2000). Solving the equations to obtain $\alpha^{2}$ and $\beta^{2}$, where the dipolar interaction constant " $P$ " between magnetic moment of the electron and vanadium nucleus can be calculated from the following equation (Gangadharmath et al., 2001) $p=$ $7 / 6\left(A_{/ /}-A_{\perp}\right)$. The spin-orbit coupling coefficient, $\lambda$, is
Vol.2 No 3 (Mar. 2009)

ISSN: 0974- 6846

assumed to be $170 \mathrm{~cm}^{-1}$ for $\mathrm{VO}^{2+}$ ion and $E$ is the electronic transition energy of ${ }^{2} \mathrm{~B}_{2} \rightarrow{ }^{2} \mathrm{E}$ and $\mathrm{k}$ is the Fermi contact term which is directly related to the isotropic hyperfine coupling and represents the amount of unpaired electron density at the nucleus.

Eukaryotic DNA degradation test Examining the DNA degradation assay for $\mathrm{H}_{6} \mathrm{DPOH}$ and its metal complexes revealed variability on their immediate damage on the calf thymus (CT) DNA. The complexes have a higher effect on the calf thymus DNA than the ligand itself, with the $\mathrm{VO}^{2+}$ and $\mathrm{ZrO}^{2+}$ complexes degrading the CT DNA completely (Fig. 4). The results suggest that direct contact of $\mathrm{VO}^{2+}$ and $\mathrm{ZrO}^{2+}$ is necessary to degrade the DNA of Eukaryotic subject. The ligand and its metal complexes were tested against gram-positive (BT) and gram negative bacteria (E. coli). All compounds have small inhibitory effects on bacteria.

\section{Separation of $\mathrm{ZrO}^{2+}$ using $\mathrm{H}_{6} \mathrm{DPOH}$}

Different factors affecting the flotation of $\mathrm{ZrO}^{2+}$ using $\mathrm{H}_{6} \mathrm{DPOH}$ have been studied to maximize its separation efficiency. The most important are:

$\mathrm{pH}$ : A series of experiments were carried out to show the effect of $\mathrm{HCl}$ and/or $\mathrm{NaOH}$ on the separation of $0.5 \times 10^{-4}$

Fig. 3. ESR spectrum of $\left[\mathrm{VO}\left(\mathrm{H}_{4} \mathrm{DPOH}\right)\left(\mathrm{H}_{2} \mathrm{O}\right)_{2}\right]$

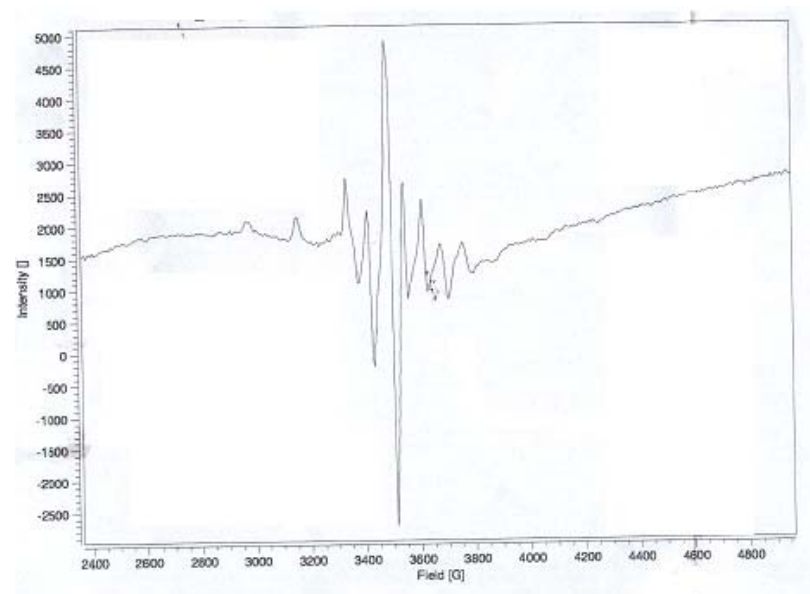

Research article

CIndian Society for Education and Environment (iSee)
"New method of $\mathrm{ZrO}^{2+}$ separation" http://www.indjst.org
El-Asmy et al. Indian J.Sci.Technol. 
$\mathrm{mol} \mathrm{I}^{-1} \mathrm{ZrO}^{2+}$, in the presence of $1 \times 10^{-5} \mathrm{~mol} \mathrm{I}^{-1}$ oleic acid (HOL) and $1 \times 10^{-4} \mathrm{~mol} \mathrm{I}^{-1} \mathrm{H}_{6} \mathrm{DPOH}$. The results show that the floatability of $\mathrm{ZrO}^{2+}-\mathrm{H}_{6} \mathrm{DPOH}$ increases with increasing the $\mathrm{pH}$, reaching a maximum at 2.5-3.5. Therefore, all work experiments were carried out at $\mathrm{pH}^{\sim}$ 3.

Ligand concentration: The efficiency does not exceed $35 \%$ on floating the $\mathrm{ZrO}^{2+}$ ions alone with oleic acid. $\mathrm{H}_{6} \mathrm{DPOH}$ was found to be the reagent added to give good results. The floatability of a series of solutions containing $0.5 \times 10^{-4} \mathrm{~mol} \mathrm{I}^{-1} \mathrm{ZrO}^{2+}, 1 \times 10^{-5} \mathrm{~mol} \mathrm{I}^{-1} \mathrm{HOL}$ and various amounts of $\mathrm{H}_{6} \mathrm{DPOH}$ at $\mathrm{pH} \sim 3$ was performed. The results show a maximum efficiency $(98.4 \%)$ at $1: 2$ (ZrO: $\mathrm{H}_{6} \mathrm{DPOH}$ ) ratio. Excess ligand has no effect, so the procedure find application for real samples containing $\mathrm{ZrO}^{2+}$. A concentration of $\mathrm{H}_{6} \mathrm{DPOH}$ equals two-folds of $\mathrm{ZrO}^{2+}$ or more was used.

Surfactant concentration: $\mathrm{ZrO}^{2+}$ ions were separated using various concentrations of $\mathrm{HOL}$; the results show maximum floatability at $1 \times 10^{-5}$ - $3.36 \times 10^{-2} \mathrm{~mol} \mathrm{I}^{-1}$ of HOL, above which the flotation decreases. Accordingly, $1 \times 10^{-5} \mathrm{~mol} \mathrm{I}^{-1} \mathrm{HOL}$ was the desired concentration.

$\mathrm{ZrO}^{2+}$ concentration: Various amounts of $\mathrm{ZrO}^{2+}$ were floated in the presence of $1 \times 10^{-4} \mathrm{~mol} \mathrm{I}^{-1} \mathrm{H}_{6} \mathrm{DPOH}$ using $1 \times 10^{-5} \mathrm{~mol} \mathrm{I}^{-1}$ $\mathrm{HOL}$ at $\mathrm{pH} \sim 3$. The floatability reaches $98.2 \%$ at $0.5 \times 10^{-4}$ $\mathrm{mol} \mathrm{I}^{-1}$ of $\mathrm{ZrO}^{2+}$ corresponding to $1: 2$ ( $\left.\mathrm{ZrO}: \mathrm{H}_{6} \mathrm{DPOH}\right)$. At higher concentration of $\mathrm{ZrO}^{2+}$, the efficiency decreases and needs excess $\mathrm{H}_{6} \mathrm{DPOH}$.

Temperature: Solutions of $\mathrm{ZrO}^{2+}, \mathrm{H}_{6} \mathrm{DPOH}$ and $\mathrm{HOL}$ were either heated or cooled; $\mathrm{HOL}$ was quickly poured into the mixture and introduced into the flotation cell. No change in the floatability $\%$ in the temperature range $0-70^{\circ} \mathrm{C}$. Since the industrial waste waters are usually hot, the introduced procedure finds successful application in the direct analysis of $\mathrm{ZrO}^{2+}$ ions. The subsequent measurements were carried out at room temperature $\sim 30$ ${ }^{\circ} \mathrm{C}$.

Foreign ions: Separation of $\mathrm{ZrO}^{2+}\left(0.5 \times 10^{-4} \mathrm{~mol} \mathrm{I}^{-1}\right)$ using $\mathrm{H}_{6} \mathrm{DPOH}\left(1 \times 10^{-4} \mathrm{~mol}^{-1}\right)$ and oleic acid $\left(1 \times 10^{-5} \mathrm{~mol} / \mathrm{L}\right)$ was carried out at higher concentrations of various cations and anions usually found in some water samples (Table 4). Tolerable amount (presented as ion: ZrO ratio) gave a maximum error of $\pm 2 \%$ in the flotation efficiency. All the investigated ions did not interfere except $\mathrm{Mn}^{2+}$, $\mathrm{Zn}^{2+} \mathrm{Cu}^{2+}, \mathrm{Al}^{3+}, \mathrm{HPO}_{4}^{-}$and citrate ions. The interference is diminished by adding excess $\mathrm{H}_{6} \mathrm{DPOH}$. Thus, the introduced procedure is fairly selective and can be safely employed for the separation and determination of $\mathrm{ZrO}^{2+}$ in various materials. lonic strength: The effect of some salts on the flotation efficiency of $0.5 \times 0^{-4} \mathrm{~mol} \mathrm{I}^{-1} \mathrm{ZrO}^{2+}$ is studied. The salts used were similar to those in natural water samples. The ionic strength of the medium has no effect on the flotation process.

Application To apply the recommended procedure for separation and determination of $\mathrm{ZrO}^{2+}$ in water samples taken from different locations, 5.36 or $10.71 \mathrm{ppm}$ of $\mathrm{ZrO}^{2+}$ was added to $10 \mathrm{ml}$ of clear water and the $\mathrm{pH}$ was adjusted to $\sim 3$ at $30^{\circ} \mathrm{C}$. After flotation, the concentration of $\mathrm{ZrO}^{2+}$ was determined spectrophotometrically using mother liquor. From the data obtained (Table 5), $\mathrm{ZrO}^{2+}$ ions can be determined with satisfactory results.

\section{Conclusion}

A new chelating agent has been prepared and characterized for chelation with $\mathrm{VO}^{2+}, \mathrm{ZrO}^{2+}$, $\mathrm{HfO}^{2+}, \mathrm{MoO}_{2}{ }^{2+}$ and $\mathrm{UO}_{2}{ }^{2+}$ as well as $\mathrm{Cr}(\mathrm{III})$. It chelates as mononegative bidentate and forms mononuclear complexes with all metal ions except $\mathrm{ZrO}^{2+}$ which forms binuclear complex. The complexes seem to be polymeric in nature due to their insolubility and high melting points. $\left[\mathrm{Cr}\left(\mathrm{H}_{4} \mathrm{DPOH}\right)\left(\mathrm{H}_{2} \mathrm{O}\right)_{3} \mathrm{Cl}\right]$ $\mathrm{H}_{2} \mathrm{O}$, [ $\left.\mathrm{HfO}\left(\mathrm{H}_{4} \mathrm{DPOH}\right)\left(\mathrm{H}_{2} \mathrm{O}\right)\right] \mathrm{H}_{2} \mathrm{O}$, [ $\left.\mathrm{MoO}_{2}\left(\mathrm{H}_{4} \mathrm{DPOH}\right)\right]$ and $\left[\mathrm{UO}_{2}\left(\mathrm{H}_{4} \mathrm{DPOH}\right)\left(\mathrm{H}_{2} \mathrm{O}\right)_{2}\right] 2 \mathrm{H}_{2} \mathrm{O}$ have been proposed to be octahedral; $\quad\left[(\mathrm{ZrO})_{2}\left(\mathrm{H}_{2} \mathrm{DPOH}\right)\left(\mathrm{C}_{2} \mathrm{H}_{5} \mathrm{OH}\right)_{2}\right]$ is four coordination, where $\left[\mathrm{VO}\left(\mathrm{H}_{4} \mathrm{DPOH}\right)\left(\mathrm{H}_{2} \mathrm{O}\right)_{2}\right]$ is square based pyramid. $\mathrm{VO}^{2+}$ and $\mathrm{Cr}(\mathrm{III})$ complexes degrade the DNA of Eukaryotic subject completely. The flotation technique was found applicable for the separation of $0.5 \times 10^{-4} \mathrm{~mol} \mathrm{I}^{-1} \mathrm{ZrO}^{2+}$ ions using $1 \times 10^{-4} \mathrm{~mol} \mathrm{I}^{-1} \mathrm{H}_{6} \mathrm{DPOH}$ and $1 \times 10^{-5} \mathrm{~mol} \mathrm{I}^{-1}$ oleic acid at $\mathrm{pH} 3$.

\section{References}

1. Al-Gammal OA and El-Asmy AA (2008) Synthesis and spectral characterization of 1-(amino-N-phenylform)-4ethylthiosemicarbazide and its metal complexes. Coord. Chem. 61 (14), 2296-2306.

2. El-Asmy AA, Khalifa ME and Hassanian MM (1998) Synthesis and spectroscopic studies on novel transition metal complexes of 3-oximino-3-(2pyridylcarbamoyl) propane-2-one. Synth. React. InorgMet-Org. Chem. 28 (6), 873-892.

3. El-Asmy AA, Khalifa ME and Hassanian MM (2004) Synthesis and characterization of transition metal complexes containing oxime, amido and thioamido groups. Ind. J. Chem. 43A, 92-97.

4. El-Asmy AA, Hafez MA, Saad EM and Taha FT (1994) Electrochemical synthesis of benzoylglycine and ethylphthaloylglycine complexes of transition metal ions. Transition Met. Chem. 19, 603-605.
Research article

CIndian Society for Education and Environment (iSee)
"New method of $\mathrm{ZrO}^{2+}$ separation"

http://www.indjst.org
El-Asmy et al. Indian J.Sci.Technol. 
5. El-Asmy AA, Khalifa ME and Hassanian MM (2001) Synthesis of mono and binuclear complexes of oximinoacetoacetanilide-4-phenylthiosemicarbazone. Synt. React. Inorg- Met- Org. Chem. 31 (10), 17871801.

6. El-Asmy AA, Khalifa ME, Rakha TH, Hassanian MM and Abdallah AM (2000) Mono and trinuclear complexes of oximinoacetoacetyl-pyridine-4-phenyl thiosemicarbazone. Chem. Pharm. Bull. 48(1), 41-44.

7. El-Asmy, AA Al-Gammal OA and Saleh H (2008) Spectral thermal, electrochemical and analytical studies on $\mathrm{Cd}(\mathrm{II})$ and $\mathrm{Hg}(\mathrm{II})$ thiosemicarbazone complexes. Spectrochimica Acta. 71, 39-44.

8. El-Metwally NM and El-Asmy AA (2006) Chelating activity of bis(diacetylmonoxime)thiocarbohydrazone towards $\mathrm{VO}^{2+}, \mathrm{Co}(\mathrm{II}), \mathrm{Ni}(\mathrm{II}), \mathrm{Cu}(\mathrm{II})$ and $\mathrm{Pt}(\mathrm{IV})$ ions. Coord. Chem. 59 (14), 1591-1601.

9. El-Metwally NM, El- Shazly RM, Gabr IM and ElAsmy AA (2005) Physical and spectroscopic studies on novel vanadyl complexes of some substituted thiosemicarbazides. Spectrochim. Acta. 61(A),1113 1119.

10.El-Metwally NM, Abou-Hussen AA and El-Asmy AA (2006) Synthesis and spectroscopic characterization of oxalyl bis-(diacetylmonoximehydrazone) metal complexes. IJPAC 1, 75-81.

11.El-Sonbati AZ, Diab MA and El-Asmy AA (1989) Uranium( $\mathrm{VI})$ complexes of some Schiff bases derived from hydroxyaromatic aldehyde and ketone. Synth. React. Inorg. Met-Org. Chem. 19(7), 731-740.

12. Gangadharmath UB, Annigeri SM, Naik AD, Revankar VK and Mahale VB (2001) Synthesis, characterisation and evaluation of molecular-orbital parameters, spinorbit, dipolar and fermi-contact terms of $\mathrm{VO} 2+$ ion in thiosemicarbazone complexes. J. Mol. Struct. 572, 6171.

13. Huo LH, Lu ZZ, Gao Shan Zhao, Hui NG and Seik Weng (2004) Bis[ $\mu$-3-(hydroxyimino)butan-2-one benzoylhydrazonato]bis[pyridinecopper(II)] methanol solvate. Acta. Cryst. E60, 1611-1613.

14.Jones LH (1958) Systematics in the vibrational spectra of uranyl complexes Spectrochim. Acta. 10, 395-403.

15.Khasa S, Seth VP, Gahlot PS, Agarwal A, Krishna RM and Gupta SK (2003) Electron paramagnetic resonance, optical transmission spectra and DC conductivity studies of vanadyl-doped alkali halide borate glasses. Physica B. 334, 347-358.

16.Kiverlson D and Lee SK (1964) ESR Studies and the Electronic Structure of Vanadyl Ion Complexes. J. Chem. Phys. 41, 1896-1903.

17.Latha KP, Vaidya VP and Keshavayya (2004) Comparative Studies on Metal Complexes of 2-Acetylnaphtho[2,1-b]furan Oxime and 2-Benzoylnaphtho[2,1-b]furan Oxime Synth. React. Inorg-Met-Org. Chem. 34(4), 667-686.

18.McGlynn SP and Smith JK (1961) Electronic Structure, Spectra, and Magnetic Properties of Oxycations. III.
Ligation Effects on the Infrared Spectrum of the Uranyl Ion. J. Chem. Phys. 35,105-116.

19.McGlynn SP, Smith JK and Neely WC (1961) The electronic structure, spectra, and magnetic properties of actinyl ions: Part I. The uranyl ion. J. Mol. Spectrosc. 6,164-187.

20.McMaster T, Garducci MD, Yang YS, Solomon EI and Enemark JH (2001) Electronic Spectral Studies of Molybdenyl Complexes. 2. MCD Spectroscopy of [MoOS4]- Centers. Inorg. Chem. 40(4), 687-702.

21. Mostafa MM, El-Asmy AA and Ibrahim GM (1983) The direct electrochemical synthesis of tin, cobalt, copper, zinc, cadmium and silver 7-formyl-8-hydroxyquinoline complexes. Trans. Met Chem. 8, 54-56.

22.Periin DD (1976) Topics in Current Chemistry. Springer Verlag, New York. p: 181.

23.Raman N, Kulandalsamy A and Thangaraja C (2003) Redox and antimicrobial studies of transition metal(II) tetradentate Schiff base complexes. Transition Met. Chem. 28, 29-36.

24.Ranford JD, Vittal JJ and Wang YM (1998) Dicopper(II) complexes of the antitumor analogues acylbis(salicylaldehyde hydrazones) and crystal structures of monomeric [Cu(2)(1,3-propanedioyl bis(salicylaldehyde hydrazone) $)(\mathrm{H}(2) \mathrm{O})-(2)] .(\mathrm{ClO}(4))$ (2). $3 \mathrm{H}(2) \mathrm{O}$ and polymeric $[\{\mathrm{Cu}(2)(1,6$-hexanedioylbis (salicyl-aldehydehydrazone) $)(\mathrm{C}(2) \mathrm{H}(5) \quad \mathrm{OH})(2)\}(\mathrm{m})()]$ $(\mathrm{ClO}(4))(2)(\mathrm{m})() \cdot \mathrm{m}(\mathrm{C}(2) \mathrm{H}(5) \mathrm{OH})$. Inorg. Chem. $37(6)$, 1226-1231.

25. Saracoglu H, Duran C, Soylu S, Andac O, Bati H and Calisken N (2004) 3-[(2,4-Dinitrophenyl)hydrazono] butan-2-one oxime. Acta Cryst. (E) 60, 1307-1309.

26.Shallaby AM, Mostafa MM, Ibrahim KM and Moussa MNH (1984) New uranyl(VI) complexes with hydrazone-oximes derived from aromatic acid hydrazides and biacetyl-monoxime. Spectrochim. Acta. 40A, 999-1002.

27.Syamal A and Ram Maurya M (1986) Synthesis and characterization of new dioxomolybdenum(VI) complexes of ONS donor Schiff bases derived from thiosemicarbazide, S-methyldithiocarbazate, Sbenzyldithiocarbazate and o-hydroxy-aromatic aldehydes/ketones. Transition . Chem. 11, 255-258.

28. Thaker BT, Lekhadia J, Potel A and Thaker P (1994) Mononuclear and long-range single-bridged binuclear complexes of oxovanadium(IV) involving conjugated heterocyclic nitrogen base and heterocyclic B-diketones. Transition Met. Chem. 19, 623-631.

29.Vogel Al (1994) Text book of quantitative inorganic analysis. Longmans, London.
El-Asmy et al. Indian J.Sci.Technol. 